\title{
THE EFFECT OF THE FINANCIAL INDEPENDENCY ON CAPITAL EXPENDITURE, INFRASTRUCTURE PERFORMANCE, ECONOMIC PERFORMANCE AND COMMUNITY WELFARE IN REGENCIES AND CITY OF BALI PROVINCE
}

\author{
Utama Made Suyana \\ University of Udayana, Bali, Indonesia \\ E-mail: suyanautama@unud.ac.id
}

\begin{abstract}
One of the functions of government is to provide services for the community, including providing infrastructure, such as roads, clean water and electricity. Infrastructure, which is often referred to as infrastructure and physical facilities, in addition to having a very strong connection with social welfare and environmental quality as well as the process of economic growth of a region. Purpose of this study to analyze the effect of local financial independency on capital expenditure, infrastructure performance, economic performance and community welfare in regencies and city in Bali Province. The data used are from secondary obtained from the Finance Bureau of Secretariat of Bali Province, and from Bali Provincial Statistics Bureau for data from 2008 to 2014. The results show that the regional financial independency has a positive effect on capital expenditure, infrastructure performance, economic performance and public welfare of the regencies and city in Bali Province. Indirectly local financial independency affects the welfare of the community in the regencies and city in Bali Province through capital expenditure, infrastructure performance, and economic performance.
\end{abstract}

\section{KEY WORDS}

Regional financial independency, capital expenditure, infrastructure performance, economic performance, community welfare.

The existence of infrastructure has a vital role in realizing the fulfillment of Basic People's Rights such as food, clothing, boards, security, education, health and others. Thus, it can be said that infrastructure is an essential capital of society that plays an important role in supporting the economic, socio-cultural, and unity and unity that bind and connect between regions in Indonesia. In order to maintain and enhance economic growth, the region is in urgent need of infrastructure development which includes transportation facilities and infrastructure, irrigation, settlement, as well as public utility buildings and networks such as gas, electricity and telecommunications. Infrastructure development is also a prerequisite for economic and social growth. Lack of effort on infrastructure development is demonstrated by routine flooding, stagnant traffic jams, constantly constrained traffic on people and goods, drought-stricken rice fields everywhere, and a host of other problems that ultimately lead to a high-cost economy.

Infrastructure, which is often referred to as infrastructure and physical facilities, in addition to having a very strong connection with social welfare and environmental quality as well as the process of economic growth of a region. This can be indicated by the indication that the area that has the completeness of the infrastructure system that works better than other regions has a level of social welfare and environmental quality and better economic growth as well. Conversely, the existence of poorly functioning infrastructure results in social and environmental problems. Directly and indirectly, infrastructure development can improve economic performance through multiple effects. Economic performance in question is economic growth, increased employment opportunities, rising per capita income (Abel, 1999). In addition, infrastructure development encourages improved socio-cultural conditions and community welfare.

Type of infrastructure in Indonesia in accordance with Presidential Decree Number 42 Year 2005 are: 1) Transportation infrastructure; 2) Road infrastructure; 3) Irrigation 
infrastructure; 4) Infrastructure of drinking water and sanitation; 5) Telematics infrastructure; 6) Infrastructure of manpower; and 7) Infrastructure of oil and gas transportation.

The development of infrastructure financed through the government budgets included in the Long Term National Development Planning (RPJMN) 2010-2014 periode is directed: 1) supporting pro-growth stimulus to the economy; 2) expanding the creation of productive employment to alleviate poverty (pro-poor). To make effective development in the regions, since 2001 all regencies in Indonesia have implemented regional autonomy or decentralization. The purpose of autonomy is for local government in carrying out its duties and functions to achieve efficient and effective and more responsible (Suwandi, 2000).

One consequence of the implementation of regional autonomy is the existence of sufficient local financial resources to finance the implementation of autonomy. The financial capacity of local government (Pemda) will determine the ability of local governments to perform functions such as performing public service functions, implementing development functions and implementing protective functions.

Sources of local revenue to finance the administration of the government, among others derived from the Original Revenue and Balancing Fund. Balancing Funds are funds sourced from APBN revenues allocated to determine on the basis of the size of the fiscal gap of an area, which is the difference between fiscal need and fiscal capacity. Increased local fiscal capacity, both as a result of obtaining balancing funds from the central government and being able to excavate itself in the form of Pendapatan Asli Daerah (PAD) can provide support to local governments to carry out their functions. The ability of regions to finance their own finances is often called regional financial independency. Regional financial independency is also called Fiscal Decentralization Degrees (DDF) is the ratio between the Original Regional Income with total expenditure area (Halim, 2001). During 2008 - 2014 the average regional financial independency or degree of fiscal decentralization (DFD) of regencies and cities in Bali Province is presented in Table 1.

Table 1 - Average of Regencies and City Financial Independency in Bali Province, 2008-2014, \%

\begin{tabular}{ccc}
\hline No. & Regencies and City & Average of DFD, \% \\
\hline 1 & Jembrana & 6.97 \\
2 & Tabanan & 16.04 \\
3 & Badung & 70.68 \\
4 & Gianyar & 21.48 \\
5 & Klungkung & 8.15 \\
6 & Bangli & 5.23 \\
7 & Karangasem & 12.62 \\
8 & Buleleng & 10.24 \\
9 & Denpasar & 33.64 \\
\hline
\end{tabular}

Source: Finance Bureau of the Provincial Secretariat of Bali, 2016 (processed).

As a consequence of the low level of regional financial independence is the lack of regional capability in providing capital expenditure and carrying out government functions, in particular is providing infrastructure, such as roads, clean water and electricity for the community. In the economic context, infrastructure is a social overhead capital that is essential capital goods that can affect economic development, and is a prerequisite for various activities of society can take place. In other words, infrastructure is the catalyst between the production process, the market and the final consumption. The existence of infrastructure provides an overview of the ability of the community to produce and the level of community welfare. Thus, high economic growth is impossible to achieve if there is no availability of adequate infrastructure or in other words infrastructure is the basic determinant or key for economic development.

The condition of infrastructure in Bali Province is almost uneven. Whereas the existence of this infrastructure has a very strong linkage with social welfare and environmental quality also to the process of economic growth of a region. Infrastructure in the study is limited to the quality of paved and in good condition of regencies / city roads, 
household coverage uses clean water, and household coverage has an electrical connection which is often called the electrification ratio. Data on infrastructure in regencies / cities in Bali Province 2014 is presented in Table 2.

Based on Table 2 it can be explained that the percentage of asphalt roads in good condition in regencies / cities in Bali Province 2014 is quite unbalanced. The best road conditions are owned by Klungkung Regency, followed by Badung Regency. The worst condition is owned by Buleleng Regency. The percentage of households that are served by PDAM's water source is Klungkung Regency, followed by Badung Regency, while the least is Kabupaten Karangasem. The coverage of households served by the flow of electricity called the ratio of electrification at most in Tabanan Regency which reached 104.80 percent, followed by Gianyar Regency. Figures that exceed one hundred percent have meaning, that in Tabanan and Gianyar Regency quite a lot of households that have electricity flow more than one connection. The regencies with the smallest electrical distribution ratio is Bangli Regency.

Table 2 - Condition of Infrastructure at Regencies and City in Bali Province 2014, \%

\begin{tabular}{ccccc}
\hline No. & Regencies and City & Road & Water & Electricity \\
\hline 1 & Jembrana & 38.83 & 64.29 & 82.93 \\
2 & Tabanan & 35.57 & 65.75 & 104.80 \\
3 & Badung & 49.22 & 72.47 & 96.95 \\
4 & Gianyar & 37.38 & 68.50 & 102.70 \\
5 & Klungkung & 57.12 & 75.18 & 93.09 \\
6 & Bangli & 28.26 & 57.82 & 72.53 \\
7 & Karangasem & 35.97 & 52.42 & 77.07 \\
8 & Buleleng & 25.50 & 54.55 & 84.62 \\
9 & Denpasar & 44.52 & 68.02 & 79.87 \\
\hline & Rata-rata & 39.15 & 64.33 & 88.28 \\
\hline
\end{tabular}

Source: Bali Membangun, 2015.

As explained earlier that the condition of infrastructure can affect the productivity of the economic sector so as to encourage economic growth and improvement of social conditions of community life through multiple effects. Several theoretical and empirical studies relate to this research. Suwandi (2001) said that the high financial capacity of the region will lead to increased regional capability to perform its functions. One of the functions of local government is to provide infrastructure for the community. Guritno (2001) also said that increased government revenues will encourage the government to increase its spending in providing services to communities so that increased incomes, unemployment and poverty are reduced.

Research on the influence of regional financial independency on capital expenditure is done by Novia Nur Putriasani (2010). The results of Denni Sulistio Mirza (2012) concluded that capital expenditure and economic growth have a positive and significant effect on HDI. Research conducted by Nur Putriasani (2014) also mentions that capital expenditure has a significant effect on infrastructure maintenance spending.

The existence of infrastructure, such as electricity positively affects the income of the poor through indirect transmission (economic growth) and direct transmission (productivity and wages) in the Philippines (Balisacan, et al, 2002) and in Bangladesh (Songco, 2002). Bangun Prasetyo and Muhammad Firdaus (2009) also concluded that the infrastructure of electricity, roads and clean water have a positive influence on the economy in Indonesia. Snieska and Ineta Simkunaite (2009) in a cross-country study concluded that infrastructure plays a role in socio-economic development, which is to improve economic performance especially to improve the quality of life of the community.

Another study conducted by Novi Maryaningsi, et al. 2014 concludes that road and electricity infrastructure conditions have a significant impact on per capita income growth in Indonesia. The World Bank 2000/2001 report in some countries in Africa entitled Attacking Poverty which concludes that the existence of infrastructure improves economic performance and economic performance improves the welfare of the community (World Bank 2001). 
Infrastructure relations with the welfare of the community are very strong, as Gibson and Rozele (2002) point out.

Based on the description, the problem is how the influence of regional financial independency on capital expenditure and infrastructure performance, next to economic performance, and prosperity of society in regencies / cities in Bali Province. This research uses quantitative analysis with design of causality relationship using Structrural Equation Modeling (SEM) with application of Partial Least Square (PLS).

\section{METHODS OF RESEARCH}

The study area covers all regency and city in Bali Province, with the research object being: Regional Revenue and Expenditure Budget, infra structure performance, economic performance, and community welfare in all or nine regencies / city in Bali Province during 2008-2014.

Regional financial independency can be seen from the degree of fiscal decentralization of a region, namely the ratio of Local Own Revenue (PAD) to total expenditure area (TPD). Total regional expenditure (TPD) is the sum of regional government expenditures, in regency / city during 2008 - 2014, in percent.

Capital expenditure is the expenditure of local government that exceeds one year budget and will add the assets or wealth of the area and then will add routine expenditure such as operation and maintenance cost, in regency / city during 2008 - 2014 in rupiah per resident.

Infrastructure defined condition of physical facility, in this case is road, water supply, and electricity is social overhead capital which is essential capital goods that can influence economic development, and is a prerequisite for various community activities. In this research infrastructure is assessed as percentage of asphalt road in good condition, percentage of household coverage using clean water, and percentage of household coverage that get electricity called electrification ratio, in regency / city during 2008 - 2014.

Measurable variables incorporated in the economic performance variables are GRDP per capita, unemployment rate, and poverty level. GRDP per capita is the total value added generated by the economic sectors within a year divided by the mid-year population. The unemployment rate is the percentage of unemployed workgroups. And the level of poverty is the percentage of the poor. All are district / municipal panel data for 2008 - 2014.

In this case the welfare of the community used Human Development Index (HDI) which is a composite index of health, education and economic indicators. Health indicators are measured using life expectancy. Educational indicators are measured by the average variable of school duration assumed to describe the ability of human resources to find and utilize knowledge and technology, in regency / municipalities during 2008 - 2014.

The data used in this research is quantitative and qualitative data. Quantitative data, ie data in the form of figures include Pendapatan Asli Daerah (PAD), and Regional Revenue and Expenditure Budget, performance of infrastructure, economic performance, and prosperity of regency / municipality community in Bali Province during 2008 - 2014. The data used in this study are secondary data consisting of realization of local revenue (PAD), and Regional Revenue and Expenditure Budget, infra structure performance, economic performance, and prosperity of regencies / city in Bali Province during 2008 - 2014. Data obtained from the Finance Bureau of the Regional Secretariat of the Provincial Government of Bali, and the Central Bureau of Statistics of Bali.

This research uses structural equation analysis (SEM) with alternative Partial Least Square PLS (component based SEM). The Structural Equation Model (SEM) is a statistical technique that allows the testing of a relatively complex series of complex relationships simultaneously and gradually. Complex relationships can be built between one or more dependent variables with one or more independent variables. In SEM, the variables may be a single indicator or a construct variable or latent variable formed by several indicators. There may also be a variable that doubles as an independent variable in a relationship, but a dependent variable on the relationship, or with a tiered causality relationship. Based on 
theoretical and implicit studies, it can be possible to establish relationships among variables in this study are presented in detail in Figure 2.1.

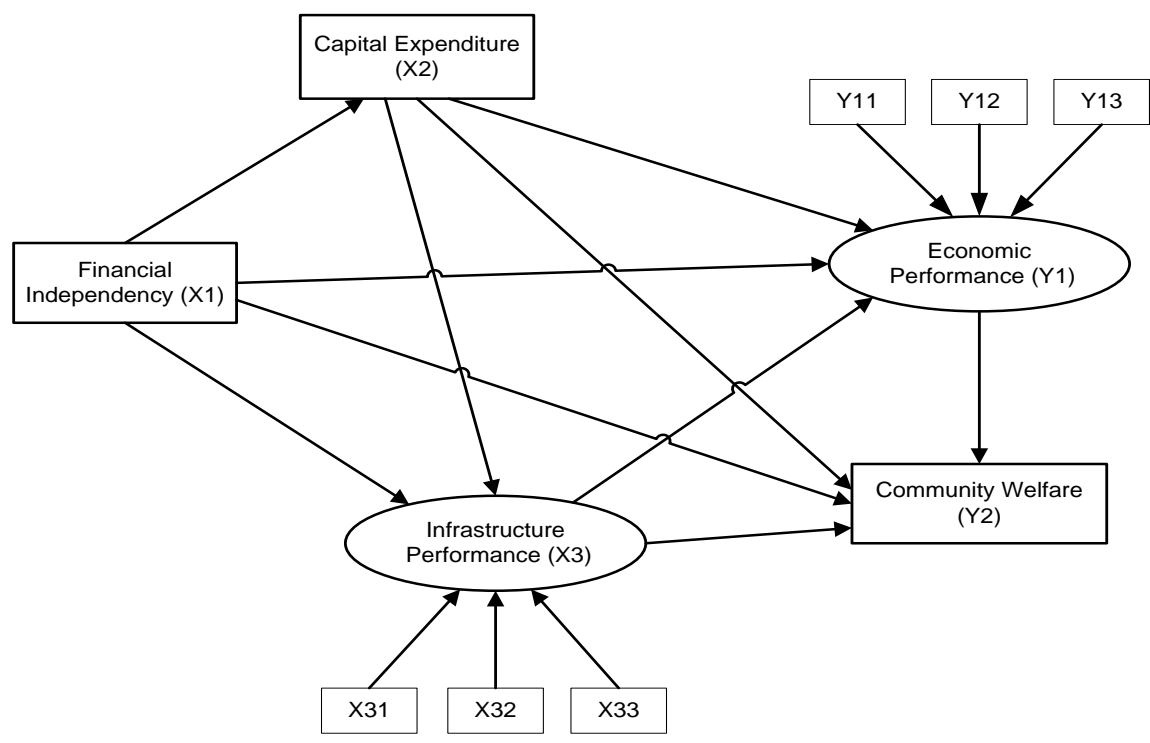

Figure 1 - Path Model

Note: $X 1=$ Financial independency; $X 2=$ Capital expenditure; $X 3=$ Infrastructure performance; $X 31=$ road; $X 32$ = water supply; $X 33$ = electricity; $Y 1=$ Economic performance; $Y 11$ = Income per capita; $Y 12$ = poverty rate; Y13 = Unemploiment rate; Y2 = Community welfare (HDI).

By using the PLS technique to specify the relationships among variables, among others: 1) outer model, 2) inner model, and 3) direct and indirect effects are described as follows. Outer model is often also called measurement model which is the relationship between indicators with latent variables. Based on Figure 3.1, there are two measurement models that are all formative indicators: a) infrastructure performance and b) regional economic performance. Infrastructure performance uses three indicators: roads, electricity and drinking water, while regional economic performance also uses indicators, namely: per capita GRDP, unemployment rate, and poverty level. The variables of regional financial independency, capital expenditure, and community welfare (IPM) in this study are single indicators so that the outer model is not evaluated.

To evaluate the validity of the outer model with formative indicators, it is necessary to observe: (1) Substantive content is to see the significance of the weight. Unsignificant formative indicators need not be excluded, as they will reduce the meaning of the construct. So the note is the outer weight, in this case the loading factor in evaluating the validity of formative constructs, and (2) Multicollinearity of the indicator by looking at the Variance Inflation Factor (VIF). VIF values above 10 indicate that there are multicolliners in the model.

In PLS inner model also called inner relation that describes the relationship between latent variables based on the substance of theory. The equation model in this study according to Figure 1 is:

$$
\begin{gathered}
X_{2}=\beta_{1} X_{1}+\varepsilon_{1} \\
X_{3}=\beta_{2} X_{1}+\beta_{3} X_{2}+\varepsilon_{2} \\
Y_{1}=\beta_{4} X_{1}+\beta_{5} X_{2}+\beta_{6} X_{3}+\varepsilon_{3} \\
Y_{2}=\beta_{7} X_{1}+\beta_{8} X_{2}+\beta_{9} X_{3}+\beta_{3} Y_{1}+\varepsilon_{4}
\end{gathered}
$$

Where: $\mathrm{X} 1=$ Regional financial independency; $\mathrm{X} 2$ = Capital expenditure; $\mathrm{X} 3=$ Infrastructure performance; $Y 1$ = Economic performance; $Y 2=$ Community welfare; $\beta 1, \beta 2 \ldots \beta 10=$ path coefficients; $\varepsilon 1 \ldots \varepsilon 4$ = inner residual.

The evaluation of the inner model is done by looking at the magnitude of its structural path coefficient, as well as its statistical t test value obtained by the bootstrapping method. In 
addition, also note R2 for the latent variable dependent. Besides R2, the PLS model can also be evaluated predictive or predictive prevelance through Stone-Geiser $Q$ Square test (Ghozali, 2011).

The influence of a variable on other variables is tested through direct influence or path coefficient, and to know the existence of the role of mediation variable on the influence of independent variable to dependent variable in PLS will automatically release the result.

\section{RESULTS AND DISCUSSION}

The economy of Bali Province has grown from 2008 to 2014. Using the Gross Regional Domestic Product (GRDP) of 2000 constant prices, the GRDP of Bali Province increased from $24,201,755$ million in 2008 to $35,593,746$ million rupiah in 2014 , or with an average growth of 6.72 percent, as presented in Table 3.1. While in the same period per capita income increased from Rp 6,883,000, - in 2008 to Rp 9,671,000, - in 2014, or with an average increase of 5.79 percent. There is a lower per capita income growth compared to GRDP growth due to population growth in the research area.

Table 3 - GRDP and Per Capita GRDP Based on Constant Price Year 2000 Regencies / City in Bali Province, Year 2008 and 2014

\begin{tabular}{ccccccc}
\hline \multirow{2}{*}{ № } & Kabupaten / Kota & \multicolumn{3}{c}{$\begin{array}{c}\text { GRDP In Constan Price Year 2000 } \\
\text { (Rp billiun) }\end{array}$} & \multicolumn{2}{c}{ Per Capita GRDP in Constan Price Year 2000 } \\
\cline { 3 - 7 } & & 2008 & 2014 & Growth (\%) & 2008 & 2014 \\
\cline { 3 - 7 } (Rp million)
\end{tabular}

Source: Statitic Centre Board of Bali Province, Year 2010 and 2014 (processed).

In addition to economic growth and per capita income, the economic performance of a region can also be seen from the poverty level as well as the unemployment rate. The poverty rate in Bali Province during 2008 to 2014 also has a downward trend, albeit fluctuatingly, as presented in Table 4. In 2008 the poverty rate or percentage of poor people in Bali Province was 5.85 percent, and in 2014 decreased to 4.76 percent. In 2008 the region with the highest poverty rate was Jembrana, which was 7.97 percent, while the lowest was Denpasar with 2.19 percent. In 2014 the region with the highest poverty rate is Klungkung Regency, which is 7.01 percent, while the lowest remain in Denpasar at 2.21 percent.

Table 4 - Poverty Rate at Regencies / City in Bali Province, Year 2008 - 2014 (Percent)

\begin{tabular}{ccccccccc}
\hline No & Dictrict/City & 2008 & 2009 & 2010 & 2011 & 2012 & 2013 \\
\hline 1 & Jembrana & 7,97 & 6,80 & 8,11 & 6,56 & 5,74 & 5,56 & 5,83 \\
2 & Tabanan & 6,92 & 4,99 & 6,96 & 5,62 & 4,90 & 5,21 \\
3 & Badung & 3,28 & 3,28 & 3,23 & 2,62 & 2,16 & 2,45 & 2,61 \\
4 & Gianyar & 6,61 & 5,76 & 6,68 & 5,40 & 4,69 & 4,27 & 4,57 \\
5 & Klungkung & 7,03 & 5,23 & 7,58 & 6,10 & 5,37 & 7,01 & 7,01 \\
6 & Bangli & 6,12 & 5,18 & 6,41 & 5,16 & 4,52 & 5,45 \\
7 & Karangasem & 7,67 & 6,37 & 7,95 & 6,43 & 5,63 & 6,88 \\
8 & Buleleng & 7,45 & 5,95 & 7,35 & 5,93 & 5,19 & 6,31 & 6,70 \\
9 & Denpasar & 2,19 & 2,20 & 2,21 & 1,79 & 1,52 & 2,07 \\
\hline
\end{tabular}

Source: Bali Central Bureau of Statistics, Year 2015.

Table 5 shows the open unemployment rate in Bali Province from 2008 to 2014 has a downward trend, albeit somewhat volatile. In 2008 the open unemployment rate was 3.3 percent, and in 2014 to 1.90 percent. In 2008 the highest open unemployment rate occurred 
in Denpasar City of 4.4 percent and the lowest in Bangli Regency of 2.6 percent. By 2014 the highest open unemployment rate occurs in Jembrana District at 2.95 percent, while the lowest is still in Bangli Regency, at 0.67 percent.

Table 5 - Unemployment Rate Open to Regencies / City in Bali Province, Year 2008-2014

\begin{tabular}{ccccccccc}
\hline No & Regencies/City & 2008 & 2009 & 2010 & 2011 & 2012 & 2013 & 2014 \\
\hline 1 & Jembrana & 4,1 & 2,23 & 2,54 & 2,17 & 1,76 & 3,39 & 2,95 \\
2 & Tabanan & 2,8 & 2,73 & 1,07 & 1,80 & 2,22 & 0,79 & 2,25 \\
3 & Badung & 3,2 & 3,20 & 1,25 & 2,30 & 1,60 & 0,77 & 0,48 \\
4 & Gianyar & 2,8 & 2,91 & 2,36 & 2,16 & 1,72 & 2,16 & 1,43 \\
5 & Klungkung & 4,0 & 3,73 & 3,59 & 1,78 & 2,05 & 2,12 & 1,94 \\
6 & Bangli & 2,6 & 1,42 & 0,65 & 1,00 & 0,95 & 0,75 & 0,67 \\
7 & Karangasem & 3,2 & 3,32 & 2,82 & 1,99 & 1,34 & 1,34 & 2,06 \\
8 & Buleleng & 2,9 & 2,34 & 3,26 & 1,97 & 3,15 & 2,13 & 2,74 \\
9 & Denpasar & 4,4 & 5,19 & 6,57 & 3,69 & 2,41 & 2,64 & 2,32 \\
\hline
\end{tabular}

Source: Bali Central Bureau of Statistics, Year 2015.

One of the important development indicators is the Human Development Index (HDI). The value of $\mathrm{HDI}$ is measured by three indicators as a reference that is life expectancy, literacy rate and real income per capita. Thus, the welfare state is a composite index of health, education and economic indicators. Health indicators are measured using life expectancy. Educational indicators are measured by the average average length of school that is assumed to describe the ability of human resources to find and utilize knowledge and technology.

HDI in Bali Province during 2008 to 2014 has an increasing trend. In 2010 Bali's HDI had decreased, and its ranking decreased from the 14th national level to the 15th rank. But it continues to increase, and in 2014 ranked 5th after the calculation of HDI is perfected by the government (Bappenas).

Table 6 - Human Development Index (HDI) of Regencies / Cities in Bali Province, Year 2008-2014

\begin{tabular}{ccccccccc}
\hline No & Regencies/City & 2008 & 2009 & 2010 & 2011 & 2012 & 2013 & 2014 \\
\hline 1 & Jembrana & 72,02 & 72,45 & 66,70 & 67,53 & 67,94 & 68,39 & 68,67 \\
2 & Tabanan & 73,73 & 74,26 & 70,68 & 71,35 & 71,69 & 72,31 & 72,68 \\
3 & Badung & 74,12 & 74,49 & 75,84 & 76,66 & 77,26 & 77,63 & 77,98 \\
4 & Gianyar & 72,00 & 72,43 & 71,45 & 72,50 & 73,36 & 74,00 & 74,29 \\
5 & Klungkung & 69,66 & 70,19 & 66,01 & 67,01 & 67,64 & 68,08 & 68,30 \\
6 & Bangli & 69,72 & 70,21 & 63,43 & 63,87 & 64,53 & 65,47 & 65,75 \\
7 & Karangasem & 65,46 & 66,06 & 60,58 & 61,60 & 62,95 & 63,70 & 64,01 \\
8 & Buleleng & 69,67 & 70,26 & 66,98 & 67,73 & 68,29 & 68,83 & 69,19 \\
9 & Denpasar & 77,18 & 77,56 & 79,19 & 79,77 & 80,45 & 81,32 & 81,65 \\
\hline & Bali & 70,98 & 71,52 & 70,10 & 70,87 & 71,62 & 72,09 & 72,48 \\
\hline
\end{tabular}

Source: Bali Central Bureau of Statistics, Year 2015.

Based on the result of data processing, the result of estimation of structural equation model as presented in Figure 2. To find out whether the indicator used to form the construct or latent variable is valid, and then the following analysis is performed. The first step is to evaluate the substantive content by looking at the significance of the weight for the formative indicator. Based on Figure 3.1 it can be seen that all indicators contribute significantly or with P. Value less than 0.05 to the constructed construct. The construct of the greatest infrastructure performance is formed by the electrification indicator, that is the ratio or percentage of households that get electricity flow that is 0.799 . Then followed by household indicator that get clean water, and last is the percentage of paved regency's road in good condition. Road conditions contribute the smallest, because the road conditions are often unstable, the same year repaired, the condition became good. In the same year the condition may turn to moderate or severe damage. In contrast to households that subscribe to 
electricity or drinking water, which will increase annually, and the chances of losing are very small.

The substantive content for the formative indicator in Figure 3.1 is presented in Table 3.5. In Table 3.5 it can be seen that the X3 indicator of road infrastructure is not significant with $P$. Value of 0.122 . Other indicators all relate to their respective constructs significantly with $P$. Value less than 0.05 .

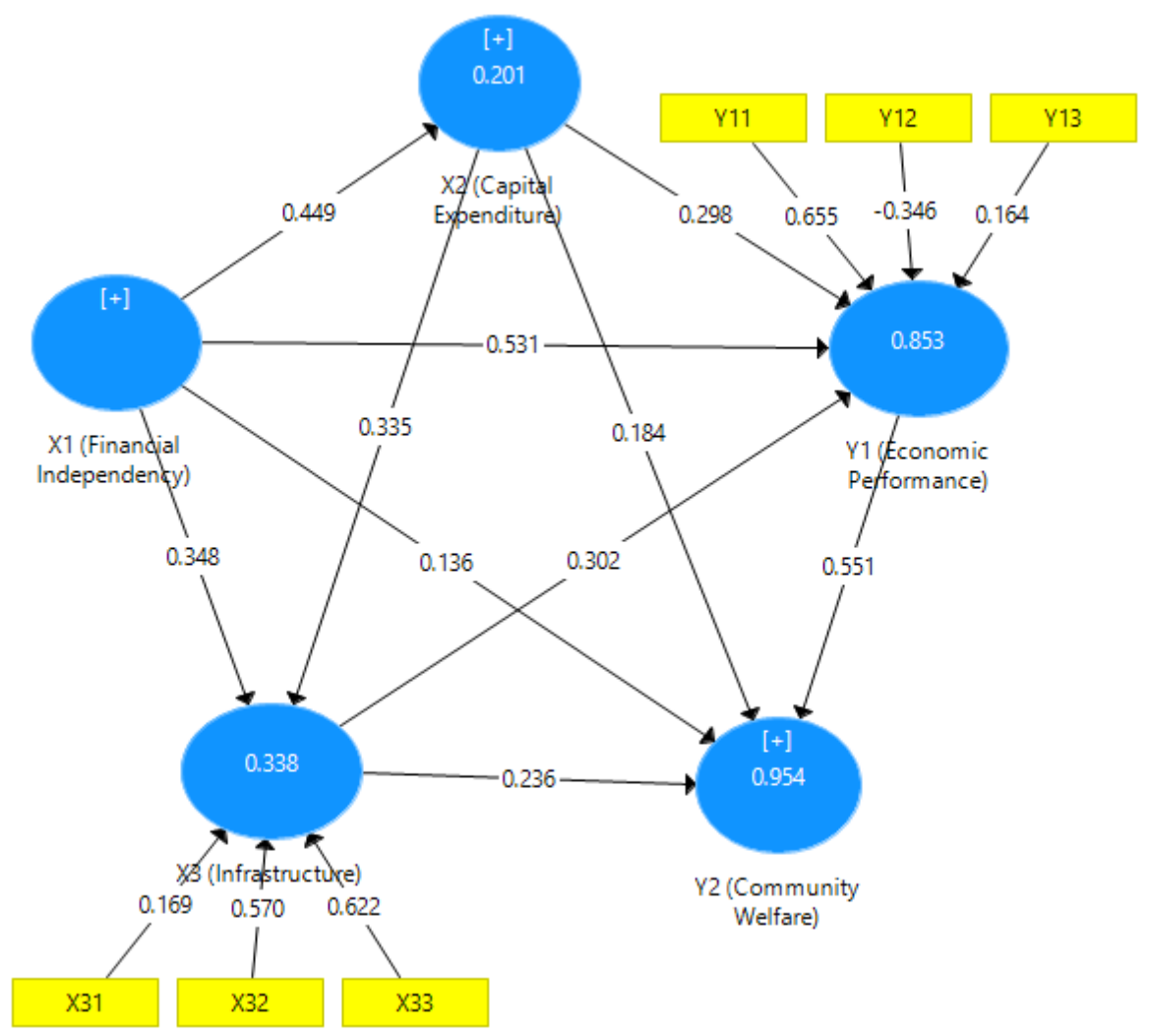

Figure 2 - Relationship among Variables

Where: $\mathrm{X} 1=$ Financial independency; $\mathrm{X} 2=$ Capital expenditure; $\mathrm{X} 3=$ Infrastructure performance; $\mathrm{X} 31$ = road; $\mathrm{X} 32$ = water suppy; $\mathrm{X} 33$ = electricity; $\mathrm{Y} 1$ = Economic Performance; $\mathrm{Y} 11$ = GRDP per capita; $\mathrm{Y} 12$ = poverty rate; $\mathrm{Y} 13$ = unemployment rate; $\mathrm{Y} 2$ = Community Welfare (HDI).

The second step to validate the formative indicator is by looking at the Variance Inflation Factor (VIF), the goal is to know the presence of multicolliners in the model. Based on Table 3.5 it is also known that all indicators are feasible to be used for prediction, since there is no multicollinearity of the indicator, becouse Variance Inflation Factor (VIF) is a maximum of 1.866 or less than 10 .

Table 7 - Outer Weights and VIF Indicators of Infrastructure Performance Constructs and Economic Performance

\begin{tabular}{llllllll}
\hline \multicolumn{2}{l}{ Variable Relationship } & Original Sampel & Standard Deviation & T Statistics & P.Value & VIF Value \\
\hline $\mathrm{X} 31$ & $\rightarrow$ & $\mathrm{X} 3$ & 0.169 & 0.109 & 1.547 & 0.122 & 1.055 \\
$\mathrm{X} 32$ & $\rightarrow$ & $\mathrm{X} 3$ & 0.570 & 0.103 & 5.542 & 0.000 & 1.149 \\
$\mathrm{X} 33$ & $\rightarrow$ & $\mathrm{X} 3$ & 0.622 & 0.099 & 6.260 & 0.000 & 1.103 \\
\hline $\mathrm{Y} 11$ & $\rightarrow$ & $\mathrm{Y} 1$ & 0.655 & 0.080 & 8.203 & 0.000 & 1.710 \\
$\mathrm{Y} 12$ & $\rightarrow$ & $\mathrm{Y} 1$ & -0.346 & 0.077 & 4.516 & 0.000 & 1.866 \\
$\mathrm{Y} 13$ & $\rightarrow$ & $\mathrm{Y} 1$ & 0.164 & 0.052 & 3.178 & 0.000 & 1.129 \\
\hline
\end{tabular}

Source: Research Result, 2016. 
Where: $\mathrm{X} 3$ = Infrastructure performance; X31 = Road; X32 = Water supply; X33 = Electricity; $\mathrm{Y} 1=$ Economic performance; $\mathrm{Y} 11=$ GRDP per capita; $\mathrm{Y} 12$ = Poverty rate; $\mathrm{Y} 13=$ Unemployment rate.

Inner model evaluation can first be seen from $R^{2}$ value of variable or endogenous construct. In this study there are four variables and endogenous constructs, namely Capital Expenditure (X2), Infrastructure Performance (X3), Economic Performance (Y1), and Welfare Society (Y2). The value of R2 for the endogenous construct is presented in Table 8.

Table 8 - R Square of Endogen Variable

\begin{tabular}{ccc}
\hline Endogen Variable & R Square & Relationship Category \\
\hline Belanja Modal $\left(\mathrm{X}_{2}\right)$ & 0,201 & Weak \\
Kinerja Infrastruktur $\left(\mathrm{X}_{3}\right)$ & 0,338 & Moderate \\
Kinerja ekonomi $\left(\mathrm{Y}_{1}\right)$ & 0,853 & Strong \\
Kesejahteraan Masyarakat $\left(\mathrm{Y}_{2}\right)$ & 0,954 & Strong \\
\hline
\end{tabular}

Source: Research Results, 2016.

The value of $R^{2}$ of the Capital Expenditure (X2) construct equals 0.201 . Because the number is smaller than 0.33 , it means that the influence of Regional Financial Independency (X1) on Capital Expenditure (X2) is weak. Then the influence of Regional Financial Independency (X1) and Capital Expenditure (X2) on Infrastructure Performance (X3) resulted in $R 2$ value of 0.338 . Since the number is greater than 0.33 tatepi smaller than 0.67 , it means that the influence of Regional Financial Independency (X1) and Capital Expenditure (X2) on Infrastructure Performance (X3) is moderate, according to Chin's opinion (in Ghozali, 2011) .

Based on the value of $R$ Square will be made calculations $Q 2$ or Stone-Geiser $Q$ Square test is:

$$
\begin{gathered}
Q^{2}=1-\left\{\left(1-R_{1}^{2}\right)\left(1-R_{2}^{2}\right)\left(1-R_{3}^{2}\right)\left(1-R_{4}^{2}\right)\right\} \\
Q^{2}=1-\{(1-0,201)(1-0,338)((1-0,853)(1-0,954)\} \\
Q^{2}=0,996
\end{gathered}
$$

The value of $Q^{2}$ of 0.996 is quite large, and can be said to have a high predictive prevelance, so the resulting model is feasible to use to predict. The Q2 of 0.996 means that 99.6 percent of the variation of Regional Financial Independency (X1), Capital Expenditure (X2), Infrastructure Performance (X3), Economic Performance (Y1) on Community Welfare (Y2), while the rest of 0.4 percent is influenced by other variables that are not installed in the model.

Based on the results of data processing can be made a direct relationship between research variables as presented in Table 9.

Table 9 - Direct Influence of Independency Variables on Dependence Variables

\begin{tabular}{ccccccc}
\hline \multicolumn{2}{l}{ Variabel Relationship } & Original Sampel (O) & Standard Deviation (STDEV) & T Statistiks (|O/STDEV $)$ & P Value \\
\hline X1 & $\rightarrow$ & X2 & 0,449 & 0,151 & 2,964 & 0,030 \\
X1 & $\rightarrow$ & X3 & 0,348 & 0,116 & 3,002 & 0,000 \\
X1 & $\rightarrow$ & Y1 & 0,531 & 0,071 & 2,490 & 0,000 \\
X1 & $\rightarrow$ & Y2 & 0,136 & 0,067 & 2,806 & 0,000 \\
X2 & $\rightarrow$ & Y3 & 0,335 & 0,119 & 4,260 & 0,000 \\
X2 & $\rightarrow$ & Y1 & 0,298 & 0,070 & 2,601 & 0,000 \\
X2 & $\rightarrow$ & Y2 & 0,184 & 0,071 & 4,020 & 0,000 \\
X3 & $\rightarrow$ & Y1 & 0,302 & 0,075 & 3,130 & 0,000 \\
X3 & $\rightarrow$ & Y2 & 0,236 & 0,075 & 3,716 & 0,000 \\
Y1 & $\rightarrow$ & Y2 & 0,551 & 0,148 & & 0,000 \\
\hline
\end{tabular}

Resource: Research Result, 2016.

Where: $\mathrm{X} 1=$ Financial independency; $\mathrm{X} 2=$ Expenditure capital; $\mathrm{X} 3=$ Infrastructure performance; $\mathrm{Y} 1$ = Economic performance; $\mathrm{Y} 2$ = Community welfare (HDI). 
The biggest variable affecting economic performance is regional finance independency of 0,531 , and then followed by variable of infrastructure performance equal to 0,302 , and last capital expenditure equal to 0,298 . The welfare of the community is greatly influenced by the economic performance of 0.551 , and the smallest regional financial independency of 0.136 . Based on the result of indirect effect the influence of independent variable to the dependent variable, through the mediation variable or the intermediate variable, in this research is the service performance variable. The results are presented in Table 10. Based on Table 10 it can be explained that capital expenditure (X2) variables are slightly less significant mediate the influence of local financial independency on infrastructure performance. This can be seen from the $P$. Value of 0.063 which is smaller than the significance level of 0.05 commonly used in socioeconomic research. Furthermore, other relationships are successfully mediated by their respective mediation variables.

Table 10 - Indirect Effect or Mediation

\begin{tabular}{|c|c|c|c|c|c|c|c|}
\hline \multicolumn{3}{|c|}{$\begin{array}{c}\text { Variable } \\
\text { Relationship }\end{array}$} & $\begin{array}{c}\text { Original Sampel } \\
(\mathrm{O})\end{array}$ & $\begin{array}{l}\text { Variabel } \\
\text { Mediasi }\end{array}$ & $\begin{array}{c}\text { Standard Deviation } \\
\text { (STDEV) }\end{array}$ & $\begin{array}{c}\text { T Statistiks } \\
(|\mathrm{O} / \mathrm{STDEV}|)\end{array}$ & $\begin{array}{c}\mathrm{P} \\
\text { Value }\end{array}$ \\
\hline $\mathrm{X} 1$ & $\rightarrow$ & X3 & 0,150 & $\mathrm{X} 2$ & 0,081 & 1,865 & 0,063 \\
\hline $\mathrm{X} 1$ & $\rightarrow$ & Y1 & 0,284 & $x 2, x 3$ & 0,065 & 4,383 & 0,000 \\
\hline $\mathrm{X} 1$ & $\rightarrow$ & Y2 & 0,649 & $\mathrm{X} 2, \mathrm{X} 3, \mathrm{Y} 1$ & 0,087 & 7,496 & 0,000 \\
\hline$X 2$ & $\rightarrow$ & Y1 & 0,101 & X3, & 0,041 & 2,440 & 0,015 \\
\hline $\mathrm{X} 2$ & $\rightarrow$ & Y2 & 0,299 & $X 3, Y 1$ & 0,081 & 3,681 & 0,000 \\
\hline $\mathrm{X} 3$ & $\rightarrow$ & Y2 & 0,166 & Y1 & 0,055 & 2,997 & 0,000 \\
\hline
\end{tabular}

Resource: Research Result, 2016.

Where: $\mathrm{X} 1=$ Financial independency; $\mathrm{X} 2=$ Expenditure capital; $\mathrm{X} 3=$ Infrastructure performance; $\mathrm{Y} 1$ = Economic performance; $\mathrm{Y} 2$ = Community welfare (HDI).

\section{DISCUSSION OF RESULTS}

Effect of Regional Financial Independency on Capital Expenditures. Regional financial independency has a positive and significant impact on capital expenditure. This finding is in accordance with the opinion of Suwandi (2000) who said that the high financial capacity of the region will lead to the ability of the region to finance its construction, in this case the availability of adequate capital expenditure to finance the construction. The financial capacity of the region is determined by the availability of sources of income (tax or retribution) and the rate of proceeds of the object of taxes and user charges. The level of outcomes is determined by the extent to which tax bases are responsive to forces affecting expense objects such as inflation, population growth and economic growth which in turn will affect service levels, both quantitatively and qualitatively (Devey, in Suwandi, 2000).

This finding is also consistent with the results of the research by Dian Adiwibowo (2005) who examined the effect of local revenues and general allocation funds on regional expenditures (case studies on regencies and municipalities in Central Java). The conclusions drawn from this study indicate that the Pendapatan Asli Daerah (PAD) and the General Allocation Fund (DAU) separately and simultaneously have a positive effect on local expenditure, and the stronger influence of the General Allocation Fund (DAU) on regional expenditure compared to the Original Income Region (PAD), so it can be inferred the occurrence of flypaper effect. The results of this study have similarities with research conducted by Novia Nur Putriasani (2010) Local Revenue (PAD) Kota Cirebon has a significant effect on capital expenditure. This means that the greater the Local Revenue (PAD) then capital spending in the City Government of Cirebon will be even greater.

Influence of Regional Financial Independency on Infrastructure Performance. Regional financial independency has a positive and significant impact on infrastructure performance. This finding is in accordance with the opinion of Suwandi (2001) who said that the high financial capacity of the region will lead to increased regional capacity to perform its functions. One of the functions of local government is to provide infrastructure for the community, such as roads, water, and electricity. The results of this study also in accordance 
with the writings of Yinqiu Lu and Tao Sun (2013) in the working paper IMF mentions that the important role of local government finances in China is for infrastructure development in order to improve economic growth.

Effect of Regional Financial Independency on Economic Performance. Regional financial independency has a positive and significant impact on economic performance. Measures of economic performance that are often noticed to know economic progress in a region or country are economic and labor growth, productivity, living standards, unemployment, inflation, saving and capital formation, and other variables (Abel and Bernake, 2001). This finding is in line with Guritno's (2001) opinion that increased government revenues will encourage governments to increase their spending on providing services to communities, resulting in increased incomes, unemployment and poverty.

Effect of Capital Expenditure on Infrastructure Performance. The results of this study indicate that capital expenditure has a positive effect on infrastructure performance. The results of this study are in accordance with Law No. 22 of 2004 that capital expenditures are expenditures for roads, irrigation and networks are expenditures used for procurement / addition / replacement / development / manufacturing and maintenance, and include expenditures for planning, supervision and management of irrigation roads and networks that add capacity to irrigation roads and networks in ready-to-use conditions. and irrigation and network roads.

This finding is consistent with the results of Nur Putriasani's (2014) study in his research at Cerebon found that capital expenditure has a significant effect on infrastructure maintenance spending. This means that the greater the capital expenditure, the greater the maintenance cost.

Effect of Infrastructure Performance on Economic Performance. This study found that infrastructure performance has an effect on economic erformance. The 2011 Bali Local Development Performance Evaluation Report mentions that in the economic context, infrastructure is a social overhead capital, which is essential capital goods that can affect economic development, and is a prerequisite for various activities of the community to take place. In other words, infrastructure is the catalyst between the production process, the market and the final consumption. The existence of infrastructure provides an overview of the ability of the community to produce and the level of community welfare. Thus, high economic growth is impossible to achieve if there is no availability of adequate infrastructure or in other words infrastructure is the basic determinant or key for economic development.

The results of this study are also in accordance with Gibson and Rozele's research, (2002) the relationship between infrastructure and poverty reduction is very strong. The study, conducted in Papua New Guinea, states that increased access to the poor to infrastructure such as roads, water and electricity has a significant effect on reducing poverty.

The results of this study are also supported by research Bangun Prasetyo and Muhammad Firdaus (2009) which concluded that the infrastructure of electricity, road and clean water have a positive influence on the economy in Indonesia. Electricity has the most important role in the production process. Therefore, the policy of infrastructure development to improve the Indonesian economy in facing the global crisis is very appropriate and needs to get support from various parties.

The results of this study are also in accordance with the results of research Novi Maryaningsi, et al. in 2014 entitled The Influence of Infrastructure on Indonesia's Economic Growth. The findings from the study suggest that road and electricity infrastructure conditions have a significant impact on per capita income growth.

Empirically, many researchers are analyzing the relationship between infrastructure such as electricity, telecommunications, roads and irrigation with poverty reduction. In the Republic of China (PRC), electricity investment has a significant role in poverty reduction, for example for every 10,000 Yuan spent on power development affecting 2.3 people (Fan et al 2002). Electricity positively affects the income of the poor through indirect transmission (economic growth) and direct transmission (productivity and wages) in the Philippines (Balisacan, et al, 2002) and in Bangladesh (Songco, 2002). 
The results of this study also supported studies conducted by Kwon in 2002 which found that every 1 percent increase in road investment is associated with a 0.3 percent decrease in poverty. In addition, using the city / county level, Balisacan et. al (2001) found that the income elasticity of poor areas through growth associated with roads was about 0.05 percent. Meanwhile in the Philippines, every 1 percent of road improvements directly relate to 0.11 percent increase in income of poor areas (Balisacan and Penia, 2002).

The Influence of Infrastructure Performance on Community Welfare. This research finds that the performance of unfrastructure has a positive effect on people's welfare. High public access to infrastructure such as roads with good conditions, drinking water, and electricity will increase community income, health and education. The results of this study susuai with research conducted by. Rioja, Felix K (2001) who conducted research in America Laitn concluded that infrastructure development has a positive impact on the growth of investment and public welfare. Similarly Snieska, and Ineta Simkunaite (2009) entitled SocioEconomic Impact of Infrastructure Investments. The cross-country research concludes that infrastructure contributes to socio-economic development, particularly to improving people's quality of life. The Ganelli, Giovanni and Juha Tervala (2015) studies concluded that infrastructure investment has provided a multiplier effect on public spending in Asia.

The Effect of Economic Performance on People's Welfare. The study also found that economic performance has an impact on the welfare of the people. Increased income per capita, reduced unemployment and poverty have a positive impact on the welfare of the community, namely increased spending, education, and public health.

This finding is consistent with the opinion of Gregory and Stuart (1992) that per capita income growth generally leads to an increase in the welfare of society. The findings of this study also in accordance with the results of research Denni Sulistio Mirza (2012) using panel data in Central Java during the year 2016 - 2009 concluded that capital expenditure and economic growth have a positive and significant impact on HDI.

The Influence of Infrastructure Performance on People's Welfare through Economic Performance. This study found that infrastructure performance can improve economic performance and improve the welfare of the community. As explained by investments invested in infrastructure through multiplier processes give multiple effects on economic performance, such as increasing per capita income, employment opportunities, and reducing poverty levels. The findings are consistent with the 2000/2001 World Bank Report in some countries in Africa entitled Attacking Poverty which concludes that the existence of infrastructure improves economic performance and economic performance improves overall welfare. Health and education degrees in low-income households as compared to highincome households. Some of the health indicators used in the study were infant mortality, malnutrition, frequency of illness, while for the education used indicator of enrollment in elementary school. Thus, it is concluded that the better the condition of the infrastructure, the higher the income of the family, the higher the access to education and health (World Bank, 2001).

\section{CONCLUSION AND SUGGESTIONS}

Regional financial independency has a positive effect on capital expenditure and infrastructure performance in the Regencies / City in Bali Province. The increase in the ratio of Own Local Revenue (PAD) to total regional expenditures will increase the allocation of capital expenditure as well as the improvement of infrastructure performance, with indicators of increasing percentage of roads with good conditions, increased service to clean water supply and electricity supply provision.

Regional financial independency, capital expenditure, and infrastructure performance have an effect on economic performance at Regencies / City in Bali Province. This means that increased regional financial independency, capital spending, and infrastructure performance have an impact on economic performance with indicators of shipping revenue and declining unemployment and the percentage of the poor. 
Regional financial independency, capital expenditure, infrastructure performance, and economic performance have a positive effect on community welfare in the Regencies / City in Bali Province. This finding means that increased regional financial independency, capital expenditure, infrastructure performance, and economic performance have a positive impact on improving people's welfare with the proxy of the Human Development Index (IPM).

Regional financial independency has a positive effect on infrastructure performance through capital expenditure at the Regencies / City in Bali Province. This means that increasing local financial independency has an effect on increasing capital expenditure allocation, and consequently improving infrastructure performance.

Infrastructure performance affects the welfare of the community through economic performance at the Regencies / City in Bali Province. The results of this study provide clues that improved infrastructure performance can improve economic performance, with indicators of per capita income, and declining unemployment and the percentage of the poor. Furthermore, with increasing economic performance, the impact of increasing the welfare of the community can be seen the increase in Human Development Index (HDI).

The influence of infrastructure performance on economic performance and also on the welfare of the community is expected to always build and maintain the infrastructure, especially the regencies roads whose condition is less than 50 percent. Given the positive relationship between capital expenditure and local government infrastructure performance, it is expected to continue to increase the proportion of capital expenditure to improve infrastructure performance, so that economic performance and public welfare will continue to increase.

\section{REFERENCES}

1. Abel, Andrew B. and Ben S. Bernake. 2001. Macroeconomics. New York: Addison Wesley Longman, Inc.

2. Ali, Ifzal and Ernesto M. Pernia, 2003. Infrastructure and Poverty Reduction. What is the Connection? Economics and Research Department Policy Brief Series Number 13. Manila, Asian Development Bank, January 2003ISSN 1655-5260

3. Balisacan, Arsenio M. and Ernesto M. Pernia, 2002. The Rural Road to Poverty Reduction: Some Lessons from the Philippine Experience. Journal of Asian and African Studies, 37: 147.

4. Bangun Prasetyo, Rindang, and Muhammad Firdaus, 2009. Pengaruh Infrastruktur Pada Pertumbuhan Ekonomi Wilayah Di Indonesia. JEKP Vol 2 No 2 Mei 2009 Department of Economics, Faculty of Economics and Management, Bogor Agricultural UniversityIndonesia.

5. Denni Sulistio Mirza, 2012. Pengaruh Kemiskinan, Pertumbuhan Ekonomi, and Belanja Modal Terhadap Indeks Pembangunan Manusia di Jawa Tengah tahun 2006-2009. Ejounal Department of Economic Development, Faculty of Economics, State University of Semarang, Indonesia.

6. Halim, Abdul, 2001. Bunga Rampai Manajemen keuangan Daerah, UPP-AMP YKPN, Yogyakarta-Indonesia.

7. Ganelli, Giovanni and Juha Tervala, 2015. The Welfare Multiplier of Public Infrastructure Investment. IMF Working Paper 16/40.

8. Ghozali, Imam, 2011. Structural Equation Modelin Metode Alternative dengan Partial Least Square. Semarang: Diponegoro University Publishing Agency.

9. Gibson and Rozele, 2002. Poverty and Access to Infrastructure in Papua New Guinea. EJournals Department of Economics, University of Waikato, Private Bag 3105, Hamilton, New Zealand.

10. Gregory, Paul. R and Robert C Stuart. 1992. Comparative Economic'System. Fourth Edition. New Jersey: Houghton Meffin Company.

11. Guritno Mangunsubroto, 2001. Ekonomi Publik. Yogyakarta: Agency Publisher Faculty of Economics Gadjah Mada University. 
12. Kwon, E. K., 2000. Infrastructure, Growth, and Poverty Reduction in Indonesia: A Crosssectional Analysis. Asian Development Bank Report, Manila.

13. Novi Maryaningsi, Oki Hermansyah, and Myrnawati Savitri. 2014. Influence Infrastructure on Indonesia's Economic Growth. Bulletin of Monetary Economics and Banking, Volume 17, Number 1, July 2014.

14. Novia Nur Putriasani, 2010. Pengaruh Pendapatan Asli Daerah (PAD) Terhadap Belanja Modal and Implikasinya Pada Belanja Pemeliharaan (Studi Pada Pemerintah Kota Cirebon). E-Jurnal Indonesian Computer Universit.

15. Nugroho Suratno Putro, 2010. Pengaruh Pertumbuhan Ekonomi, Pendapatan Asli Daerah and Dana Alokasi Umum Terhadap Pengalokasian Anggaran Belanja Modal (Study Kasus Pada Kabupaten/Kota Di Provinsi Jawa Tengah). Semarang: E-Jurnal Faculty of Economics Diponegoro University.

16. Presiden Republik Indonesia, 2005. Keputusan Presiden Nomor 42 Tahun 2005 about the Policy Committee for the Acceleration of Infrastructure Provision. Jakarta: Deputy Cabinet Secretary for Legal Affairs and Legislation.

17. Rioja, Felix K, 2001. Growth, Welfare, and Public Infrastructure: A General Equilibrium Analysis of Latin American Economies. Journal of Economic Development, Volume 26, Number 2, December 2001, p 119-130.

18. Snieska, Vytautas and Ineta Simkunaite, 2009. Socio-Economic Impact of Infrastructure Investments. Electronic Journal of Inzinerine Ekonomika-Engineering Economics Vol. 3 2009, pp $16-25$.

19. Songco, J., 2002. Do Rural Infrastructure Investments Benefit the Poor? World Bank Working Paper 2796, Washington, D.C.

20. Suwandi, Made, 2000. Agenda Strategis Penataan Otonomi Daerah (Sebagai tindak janjut UU No. 22 and UU No. 25 tahun 1999), Makalah Work Shop Otonomi Daerah, Kerjasama LPEM- UI and IRIS Jakarta.

21. Wibowo, 2002. Perhitungan Anggaran Pendapatan Belanja Daerah tahun Anggaran 1997/1998 sampai dengan 2001 sebagai Akuntabilitas Publik Pemerintah Propinsi Nusa Tenggara Timur. Thesis Undergraduate Program of Accounting Faculty of Economics Udayana University.

22. World Bank, 2001. World Development Report 2000/2001: Attacking Poverty. New York: Oxford University Press.

23. Yinqiu Lu and Tao Sun, 2013. Local Government Financing Platforms in China: A Fortune or Misfortune? IMF Working Paper WP 13/243. 